\title{
PENDASARAN TEOLOGIS BAGI PEMIKIRAN POLITIK JOHN CALVIN
}

\author{
Antonius Steven Un \\ Sekolah Tinggi Teologi Reformed Injili Internasional, Jakarta
}

\begin{abstract}
ABSTRAK: Sebagai seorang teolog, John Calvin mendasarkan pemikiran politiknya atas doktrin-doktrin teologis. Dalam kajian terhadap pemikiran politiknya, paling tidak dalam bagian pemerintahan aristokratis-demokratis, terlihat Calvin mengasumsikan sejumlah doktrin penting yakni doktrin Alkitab, doktrin kedaulatan Allah dan doktrin dosa. Ketiga doktrin ini memberi pengaruh paling tidak, bagi eksistensi pemerintahan, pentingnya hukum, dan kepemimpinan plural.
\end{abstract}

KATA KUNCI: John Calvin, kedaulatan Allah, dosa, Alkitab, pemerintahan

\begin{abstract}
As a theologian, John Calvin bases his political thought on theological doctrines. In the study on his political thought, at least in the part of aristocratic-democratic government, Calvin presupposes some important doctrines such as the Doctrine of the Bible, the Doctrine of the Sovereignty of God and the Doctrine of Sin. These doctrines influence at least in some subjects such as the existence of government, the importance of law and plural leadership.
\end{abstract}

KEYWORDS: John Calvin, sovereignty of God, sin, Bible, government. 


\section{Pendahuluan}

Sebagai seorang teolog, reformator John Calvin (1509-1564) tidak mungkin melepaskan pembicaraan politik dari teologi. Dalam kajian terhadap tulisan-tulisan Calvin, kita akan menemukan bahwa pemikiran politiknya sebenarnya merupakan implikasi dari doktrin-doktrin teologis yang sudah digagas pada bagian sebelumnya. Hal ini juga dapat dipahami dari posisi Bab 20 dari buku IV dalam masterpiece-nya Institutes of the Christian Religion yang merupakan bab terakhir dari seluruh buku tersebut. Terasa bahwa Calvin menempatkan pemikiran politik sebagai implikasi dari doktrin-doktrin teologis yang telah digagas sebelumnya. Artikel ini bermaksud menelusuri gagasan-gagasan teologis apa saja yang mendasari pemikiran politik Calvin.

Artikel ini ditulis dalam kerangka pembahasan bentuk pemerintahan aristokratis-demokratis. ${ }^{1}$ Karena itu, elemen-elemen yang diteliti berkaitan dengan hal tersebut. Artikel ini tidak membahas bagian-bagian pemikiran politik lain yang tidak berkaitan seperti tugas pemerintahan dalam pengelolaan pajak. Pendekatan yang ditempuh dalam penulisan artikel ini adalah dengan mengartikulasikan hubungan antara doktrin-doktrin teologis yang digagas Calvin dengan pemikiran politiknya. Paling tidak terdapat 3 doktrin yang dikaji dalam artikel ini yakni doktrin Alkitab, doktrin kedaulatan Allah dan doktrin dosa.

1 Lihat artikel Antonius Steven Un, “Bentuk Pemerintahan Menurut John Calvin” dalam Jurnal Teologi Sola Experientia, Vol. 2, No. 1, April 2014 (Jakarta: STT Jakarta \& Persetia), 29-49. 


\section{Doktrin Alkitab}

Calvin dan juga kemudian Calvinisme, sangat mengapresiasi tinggi Alkitab sebagai firman Allah. ${ }^{2}$ Hal ini terlihat jelas juga dalam konteks pembicaraan teologi politik. Henry Meeter mengatakan,

"Wherever you find genuine Calvinism operating in any political field, there you find the sametence upon sovereignty of God and obedience to the Word of God as it concerns matters of state... And it obviated all excuse for subjectivism and selfish individualism by adopting an objective and perfect regulative standard for man's conduct in political affairs, namely, the Bible as the Word of God."3

Bagi Calvin, wahyu umum tidak pernah sanggup membawa manusia berdosa mencapai pengetahuan sejati tentang Allah yang hidup dan benar. Calvin menggunakan tiga metafora yakni bagaikan kacamata yang diberikan kepada orang yang matanya kabur ${ }^{4}$; atau benang yang memberi arah dalam sebuah labirin yang membingungkan karena tak berujung dan Alkitab sebagai guru yang mengajarkan kita kebenaran. ${ }^{5}$ Calvin mengatakan bahwa Allah menyediakan bantuan firman Tuhan bagi manusia sebagai suatu instruksi yang berguna, di mana Allah beranggapan bahwa wahyu

2 Artikel ini tidak membahas bagaimana Calvin berdialog dengan sumber-sumber nonkanonikal/ non-Alkitab seperti pemikiran Yunani dan Cicero.

3 H. Henry Meeter, The Basic Ideas of Calvinism (Grand Rapids: Baker, 1990), 92.

4 John Calvin, Institutes of the Christian Religion, Ed. John T. McNeill (Philadelphia: Westminster, 1960), 1.6.1. Bandingkan Robert L. Reymond, "Doktrin Calvin tentang Kitab Suci" dalam Penuntun ke Dalam Theologi Institutes Calvin (Surabaya: Momentum, 2009), 49-50.

Pembahasan mengenai Bibliologi Calvin ditempatkan sebagai presaposisi teologis di balik pemikiran politik sehingga tidak akan mendetil. Pembahasan mendetil mengenai pandangan Calvin dapat dilihat pada buku tersebut dan buku-buku lain yang relevan. Misalnya, bagian introduksi dalam buku Louis Berkhof, Systematic Theology, New Combined Edition (Grand Rapids: Eerdmans, 2006).

5 Ibid., 1.6.3. 
umum melalui alam belumlah cukup menjalankan fungsi tersebut. ${ }^{6}$

Alkitab adalah firman Allah. Calvin menegaskan,

"Therefore, illumined by his power, we believe neither by our own nor by anyone else's judgement, that Scripture is from God; but above human judgement we affirm with utter certainty (just as if we were gazing upon the majesty of God himself) that it has flowed to us from the very mouth of God by the ministry of men". ${ }^{7}$

Alkitab mempunyai otoritas yang berasal dari Allah. Calvin menyatakan,

"When that which is set forth is acknowledged to be the Word of God, there is no one so deplorably insolent - unless devoid also both of common sense and of humanity itself - as to dare impugn the credibility of Him who speaks...Hence the Scriptures obtain full authority among believers only when men regard them as having sprung from heaven, as if there the living words of God were heard". ${ }^{\prime}$

Alkitab bersifat "self-authenticated" sehingga Calvin mewaspadai upaya membuktikan Alkitab sebagai firman Allah. ${ }^{10}$ Hal ini bisa dipahami dengan jelas dan sederhana. Pernyataan doktrin Alkitab adalah firman Allah tidak didasarkan kepada bukti-bukti eksternal - kecuali kesaksian Roh Kudus yang bukan merupakan bukti - tetapi pada presaposisi dan argumentasi dari dalam Alkitab sendiri. Eksistensi bukti eksternal dalam validasi Alkitab sebagai firman Allah akan menimbulkan konflik yang sulit

\footnotetext{
$6 \quad$ Ibid., 1.6.3.

7 Ibid., 1.7.5.

$8 \quad$ Ibid., 1.7.1.

9 Bahasa Yunani: autopiston. Reymond dalam catatan kaki nomor 4 mengatakan bahwa dalam terjemahan Prancis dari buku Institutes, kata-kata Calvin di sini adalah "porte avec soi sa creance" yakni "membawa dalam dirinya kredensial-kredensialnya [sendiri]" (Reymond, "Doktrin Calvin tentang Kitab Suci", 54).

10 Calvin, Institutes, 1.7.5.
} 
dipecahkan. Manakah yang lebih penting, Alkitab sebagai firman Allah atau buktinya? Apakah bila bukti tersebut berhasil diruntuhkan oleh serangan dan pembuktian lain, apakah berarti Alkitab akan terseret dan jatuh karena menyandarkan eksistensinya pada bukti?

Sebagaimana telah disinggung, pernyataan bahwa Alkitab adalah firman Allah memiliki otentisitas dalam dirinya sendiri. Karena itu, pendekatan yang dipakai adalah dengan melihat kaitan erat antara Alkitab dan Kristus yang dideklarasikan dalam Yohanes 1 sebagai firman Allah. Jika Kristus adalah firman Allah maka identifikasi Alkitab sebagi firman Allah haruslah memiliki relasi interdependensi yang luar biasa dengan Kristus. Dan Alkitab memaparkannya dengan jelas. Perjanjian Lama menubuatkan Kristus sedangkan Perjanjian Baru menceritakan tentang Kristus. ${ }^{11}$ Sementara itu, Kristus membaca dan mengakui Perjanjian Lama ${ }^{12}$, sekaligus menjadi alasan utama keberadaan Perjanjian Baru. Jadi, Kristus sebagai firman Allah adalah kriteria pembanding untuk memahami mengapa Alkitab diakui sebagai firman Allah.

Selain itu, Alkitab sebagai firman Allah, secara logika haruslah melakukan apa yang tidak bisa dilakukan oleh manusia. Alkitab mencatat awal dan akhir sejarah dengan begitu detil. Penciptaan dipaparkan secara sistematis dan spesifik sementara itu kedatangan Yesus Kristus dan kiamat

\footnotetext{
11 Lukas 24:44 menyatakan bahwa Perjanjian Lama, yang dalam versi Yahudi terdiri dari tiga bagian - Kitab Taurat, Kitab Nabi-Nabi dan Tulisan-Tulisan yang dimulai dengan Mazmur menceritakan tentang Kristus.

12 Misalnya dalam Matius 23:35. Yesus mau mengatakan bahwa pembunuhan nabi oleh orang Yahudi terjadi di sepanjang Perjanjian Lama, mulai dari Kejadian (kasus Habel) hingga 2 Tawarikh (kasus Zakaria). 2 Tawarikh adalah kitab terakhir dalam Perjanjian Lama dengan urutan yang disusun oleh Tradisi Yahudi.
} 
digambarkan setahap demi setahap (Kis. 1:9-11; 1 Tes. 4:13-18). Alkitab menuliskan 333 nubuat mengenai Kristus dalam Perjanjian Lama. Kalau bukan Allah, tidak ada manusia yang bisa memahami - apalagi memahami sebelumnya - 333 elemen identitas dari seorang manusia lain. Apalagi, 333 nubuat ini semuanya digenapi. ${ }^{13}$ Jadi, pra-identifikasi yang begitu spesifik dan penggenapan atas nubuat-nubuatnya mengiluminasikan pemahaman bahwa Alkitab bukanlah karya manusia melainkan karya Allah. Apalagi ditambah dengan tenunan terpisah 40 orang penulis selama kurun waktu 1500 tahun ternyata menghasilkan benang merah yang sama yakni Kristus, jelas menyatakan bahwa Roh Kudus berada di balik 40 orang yang berbedabeda zaman dan latar belakang tersebut.

Kepastian yang menyertai Alkitab adalah kesaksian internal Roh Kudus. ${ }^{14}$ Calvin melanjutkan bahwa fakta Allah berbicara di dalam dan melalui Alkitab merupakan dasar otentisitas Alkitab yang paling utama. ${ }^{15}$ Keuntungan dari pemahaman ini terletak pada dua sisi. Pada sisi masa lalu, nabi dan rasul, hendaklah jangan merasa diri layak karena mereka membawa serta nama Tuhan yang kudus, yang menjadikan seluruh dunia mau taat kepada mereka. Sesungguhnya pekerjaan Roh Kudus-lah yang memungkinkan semua itu terjadi. Pada sisi lain, kesaksian Roh Kudus atas

13 D. James Kennedy dan Jerry Newcombe, Bagaimana Jika Alkitab Tidak Pernah Ditulis? (Batam: Interaksara, 1999), 307. Perhatikan beberapa data yang diberikan oleh Kennedy dan Newcombe. Ia mengutip Frederich Meldau yang mengatakan bahwa hanya diperlukan lima item untuk identifikasi yang memisahkan seseorang dari seluruh penduduk di bumi ini yakni nama, nama jalan, kota, negara bagian dan negara. Sementara itu, ahli matematika Peter Stoner menyatakan bahwa peluang satu orang untuk memenuhi item-item identitas itu, bila 8 item makan peluangnya 10 pangkat 17. Bila 48 item maka peluangnya 10 pangkat 157 .

14 Calvin, Institutes, 1.7.5.

15 Ibid., 1.7.4. 
Alkitab menghasilkan suatu keyakinan pada diri orang percaya yang melampaui akal dan penghakiman manusia. Kesaksian Roh Kudus secara internal-lah yang merupakan kunci utama memahami Alkitab sebagai firman Allah. ${ }^{16}$

Epistemologi Calvin dalam teologi politik, sudah jelas tidak sematamata karena bergumul dengan pemikiran Anabaptis atau melihat realitas monarkis-tiranis pada zamannya tetapi terutama adalah pengajaran Alkitab. Alkitab bukan hanya mengajarkan bahwa Allah adalah Pencipta dan Penebus ${ }^{17}$, tetapi juga mengajarkan kebenaran bagi manusia di dalam dunia. ${ }^{18}$ Gereja dan orang percaya wajib membicarakan setiap hal yang dibicarakan Alkitab, tidak perduli berapa sulit dan kontroversialnya ayatayat tersebut. Dan teologi politik mendapat pendasaran yang menyebar di sepanjang Alkitab.

Sebenarnya bukan hanya teologi politik tetapi seluruh tema dalam Institutes selalu dibangun atas dasar pengajaran Alkitab. Calvin selalu memberikan dasar-dasar dan contoh-contoh Alkitab sebagai kekuatan dalam argumentasi-argumentasi teologisnya. Calvin membangun doktrin atau teologinya berdasarkan Alkitab melalui dua jalan yakni bukti-bukti langsung dari Alkitab dan referensi-referensi logis. Secara khusus dalam konteks teologi politik, Meeter mengatakan bahwa Allah berdaulat atas segala hal sehingga secara logika dapat diterima bahwa firman-Nya harus menjadi aturan dasar. Apabila Alkitab adalah firman Allah yang menjadi

\footnotetext{
16 Ibid., 1.7.4.

17 Ibid., 1.6.1.

18 Ibid., 1.6.2.
} 
dasar bagi seluruh kekristenan maka tidak bisa tidak, ide, isu dan implikasi kehidupan politik - tidak perduli seberapa kontroversi dan kontradiksinya harus didasarkan atas pengajaran Alkitab. ${ }^{19}$ Dengan demikian, meskipun Alkitab tidak membicarakan secara eksplisit suatu sistem politik tertentu, tetapi Alkitab memberikan prinsip-prinsip kebenaran yang kekal dan universal untuk mendasari dan mengendalikan sistem politik. ${ }^{20}$

Sebagai bukti Calvin adalah seorang yang biblical minded dalam teologi politiknya, maka kita dapat mencatat banyaknya ayat yang disebut atau dikutip dalam bab terakhir Institutes tentang pemerintahan. Kita dapat mencatat sebagian di antara banyak ayat yang disebutkan oleh Calvin: Keluaran (2:2; 8:13-26; 20:13; 22:8), Ulangan (1:9-17; 5:17), Hakim-Hakim (21:25), 1 Samuel (8:7), 2 Tawarikh (19:6-7), Mazmur (2:12; 21; 22; 45; 72; 82:1, 6; 89; 101:4-7; 110; 132;), Amsal (8:14-16; 24:21), Yesaya (3:14-15; 11:9; 49:23; 65:25), Yeremia (21:12; 22:3; 48:10), Matius (5:21), Lukas (22:25-26), Yohanes (10:35), Kisah Para Rasul (7:24), Roma (12:8; 13:2-4), 1 Korintus (7:21; 12:28), Galatia (3:28; 5:1), 1 Timotius $(2: 2,15), 1$ Petrus $(2: 17)$.

Bibliologi Calvin suatu kritikan tajam kepada Anabaptis yang mau menerima Alkitab tetapi tidak mau menerima banyaknya pernyataan dan kesaksian Alkitab bahwa pemerintah didirikan oleh Allah. ${ }^{21}$ Dalam kasus ini, Anabaptis lebih banyak dikuasai oleh pengalaman akibat banyaknya

\footnotetext{
19 Meeter, The Basic Ideas of Calvinism, 74-75. Bandingkan Meeter mengatakan bahwa karakteristik yang pertama dan terpenting dalam Calvinisme politik yang sejati adalah pengakuan akan kedaulatan Allah dan otoritas tertinggi dari Firman Allah dalam penerapannya pada kondisi politik (The Basic Ideas of Calvinism, 92).

20 Ibid., 75-76.

21 Calvin, Institutes, 4.20.7.
} 
penganiayaan pemerintah yang bekerja sama baik didukung atau mendukung kelompok Protestan dan Katolik Roma di berbagai belahan Eropa pada masa Reformasi. Secara tidak sadar, pengalaman menjadi standar kebenaran. Anabaptis telah sedang masuk ke dalam suatu epistemologi yang berbasiskan pengalaman (experiential epistemology). Padahal, pengalaman tidak boleh menjadi kebenaran. Seharusnya adalah pengalaman akan kebenaran sebagai ekspresi firman menjadi daging, masuk ke dalam realita hidup manusia. Calvin menerima doktrin inspirasi Alkitab yakni plenary inspiration ${ }^{22}$, yakni seluruh Alkitab secara utuh dan komprehensif adalam firman Allah sehingga harus diterima secara konsisten.

Doktrin inspirasi Alkitab - bahwa Alkitab adalah diilhamkan oleh Allah (2 Tim. 3:16; 2 Pet. 1:20-21) seharusnya membawa kepada hermeneutika yang berbasiskan eksegesis bukan eisegesis. Tetapi yang dilakukan oleh Anabaptis dalam penafsiran Lukas 22:25-26 23 - yang dikritik oleh Calvin - bersifat eisegesis karena memaksakan ayat itu untuk mengatakan bahwa Allah melarang orang percaya terlibat dalam pemerintahan. Calvin jelas bukan sedang melakukan eisegesis - ide yang dimasukkan ke dalam teks-teks Alkitab - tetapi eksegesis, menggali keluar ide dari dalam teks-teks Alkitab. Sebagaimana yang telah kita lihat dalam biografi politiknya, jasa guru humanis Calvin, John Major sangat besar untuk membuka pintu bagi penafsiran "the critical historico-literary, linguistic

\footnotetext{
22 Bandingkan W. Gary Carmpton, Verbum Dei (Surabaya: Momentum, 2000), 55.

23 Calvin, Institutes, 4.20.7.
} 
interpretation". ${ }^{24}$ T. F Torrance menjelaskan soal model penafsiran ini,

"the literal sense is essential, for it is upon it alone that we can build doctrine... That is why it is so important to take account of the scope of the Scriptures and to square every passage with the context not only with the immediate context of the passage in question, but with the whole context of the Gospel... The literal sense is achieved through contextual and comparative exegesis, for that establishes the real as distinct from a merely accidental meaning". ${ }^{25}$

Tafsiran-tafsiran Calvin juga menjadi sumber penting untuk memahami bentuk pemerintahan Aristokrasi-Demokrasi yang diajarkan oleh reformator kelahiran Perancis itu. Douglas F. Kelly bahkan dengan lebih jauh membukakan bahwa gagasan aristokrasi-demokrasi yang dianut Calvin sesungguhnya berhutang kepada praktek pemilihan raja-raja dalam Perjanjian Lama. Tidak cukup sampai di situ, Kelly juga menegaskan bahwa keinginan Calvin akan bentuk pemerintahan yang elektif, representatif dan republik, sudah pasti dipengaruhi oleh tahun-tahun di mana ia sering menulis dan mengkhotbahkan dari Perjanjian Lama. ${ }^{26}$

Kerajaan Utara khususnya, secara reguler mempraktekkan pemilihan populer dan pergantian raja dalam pandangan di mana Allah mengendalikan para penguasa dalam komunitas teokratis Israel. Apalagi, tradisi pemimpin Perjanjian Lama yang biasa duduk di pintu gerbang untuk menangani masalah-masalah rakyat serta eksistensi konsili 70 tua-tua yang diangkat untuk membantu Musa, tidak bisa dipungkiri memberi dampak yang besar bagi Calvin dalam membangun teologi politiknya yang

24 Douglas Kelly, The Emergence of Liberty in the Modern World (Phillipsburg: P\&R, 1992), 7.

25 Dikutip dalam Kelly, The Emergence of Liberty, 7.

26 Kelly, The Emergence of Liberty, 18. 
cenderung republikan. ${ }^{27}$ Sementara itu, David Hall menilai bahwa kebanyakan traktat politik pada era Reformasi, baik dari Calvin, Beza, Bucer, Knox, Buchanan, Ponet, Althusius dan lainnya secara khusus didasarkan pada tafsiran atas pola-pola pemerintahan dalam Perjanjian Lama. Para reformator ini beranggapan bahwa praktek-praktek pemerintahan dalam Perjanjian Lama ternyata dapat diaplikasikan dalam konteks mereka dan belakangan juga diaplikasikan dalam politik Amerika. ${ }^{28}$

\section{Doktrin Kedaulatan Allah}

\section{Defenisi Kedaulatan Allah}

Konsep kedaulatan Allah berada di balik pemikiran politik Calvin sebagaimana yang ditegaskan oleh Charles Partee,

"To his conception of church and state, Calvin applied his conviction of God's great government...I conclude that this subject and this chapter represent an integral and essential part of Calvin's doctrine of God's providence for the beloved community of the faithful" ${ }^{29}$

William Stevenson juga menandaskan penilaian serupa. Baginya, Calvin mendasarkan pemikirannya tentang perlawanan yang sah bagi otoritas politis didasarkan justru pada doktrin providensi, yang adalah bagian dari kedaulatan Allah. ${ }^{30}$ J. Philip Wogaman mengatakan bahwa kedaulatan Allah

27 Kelly, The Emergence of Liberty, 18.

28 David Hall, Calvin in the Public Square: Liberal Democracies, Rights and Civil Liberties (Phillipsburg: P\&R, 2009), 85.

29 Charles Partee, The Theology of John Calvin (Louisville: Westminster John Knox, 2008), 295.

30 William Stevenson, "Calvin and Political Issues" dalam ed, Donald McKim, The Cambridge Companion to John Calvin (Cambridge: Cambridge University Press, 2004), 181. 
adalah titik masuk utama teologi kepada diskusi politik karena kedaulatan Allah mengasumsikan bahwa Allah berdaulat atas seluruh ciptaan, sebagai pusat dan sumber bagi seluruh karya-Nya dan dengan demikian, tidak ada ciptaan yang bisa melarikan diri dari pertanggungjawaban kepada Allah. ${ }^{31}$

Louis Berkhof mengatakan bahwa kedaulatan Allah sangat ditekankan di dalam Alkitab, baik dalam presentasi Allah sebagai Pencipta; Allah yang memiliki otoritas mutlak atas segala sesuatu; Allah yang menopang segala ciptaan-Nya dengan kuasa-Nya yang luar biasa; Allah memerintah sebagai raja dalam pengertian paling mutlak; bahkan segala sesuatu bergantung kepada-Nya; serta Ia menentukan tujuan akhir segala sesuatu. ${ }^{32}$ Dalam dua buku yang awal dari Institutes, Calvin menulis dengan judul "The Knowledge of God the Creator" dan "The Knowledge of God the Redeemer in Christ, First Disclosed to the Fathers under the Law, and Then to Us in the Gospel". Hal ini sudah menunjukkan konsentrasi Calvin kepada kedaulatan Allah.

Berkhof mendefenisikan dua aspek kedaulatan Allah. Yang pertama yaitu kehendak berdaulat dari Allah, yang didefenisikan sebagai "that perfection of His being whereby He, in a most simple act, goes out towards Himself as the highest good (i.e delights in Himself as such) and towards His creatures for His own name's sake and is thus the ground of their being and continued existence." 33 Sedangkan elemen kedua adalah kuasa berdaulat dari Allah yang dimaknai sebagai "that perfection of His Being by which He is the absolute

31 J. Philip Wogaman, Christian Perspectives on Politics (Louisville: Westminster John Knox, 2000), 209.

32 Berkhof, Systematic Theology, 76.

33 Ibid., 77. 
and highest causality." 34 Secara sederhana, John Frame menjelaskan makna kedaulatan Allah dalam gambaran kontrol dan otoritas. Kontrol berarti Allah memiliki kuasa untuk mengendalikan seluruh ciptaan dan sejarah berdasarkan kemauan-Nya sendiri sedangkan otoritas berarti bahwa Allah sangat layak dan berhak untuk melakukan kontrol tersebut. ${ }^{35}$

Dengan pemahaman di atas ini, maka Calvin mengekspresikan kedaulatan Allah dalam sejumlah karya di antaranya, karya pemilihan ${ }^{36}$, penciptaan $^{37}$, dan providensi ${ }^{38}$ yang dibahas jelas dalam Institutes. Doktrin providensi $^{39}$ amat penting untuk dibahas dalam kaitan dengan teologi politik Calvin, sebagai ekspresi amat penting dari karakter kedaulatan Allah.

Adalah suatu koneksi logis antara doktrin penciptaan dan pemeliharaan. Penciptaan dapat dikatakan sebagai presaposisi bagi pemeliharaan. Firman Tuhan mendorong manusia untuk mengakui pemeliharaan dan pemerintahan Allah yang aktif atas segala sesuatu seperti yang dinyatakan dalam Mazmur 33:6, 13; 104:27-30; Kis. 17:28.40 Bagi Calvin,

\footnotetext{
34 Ibid., 79.

35 John Frame, The Doctrine of God (Phillipsburg: P\&R, 2002), 80.

36 Calvin, Institutes, 3.21-24.

37 Ibid., 1.14 .

38 Ibid., 1.16-18.

39 Penulis tidak akan membahas secara mendetil mengenai doktrin providensi. Sebab kepentingan doktrin providensi di sini adalah, looking backward, kepada adalah ekspresi kedaulatan Allah. Sedangkan looking forward, melihat providential character dalam pemerintahan yang ditetapkan oleh Allah. Mengenai doktrin providensi Calvin, perhatikan pembahasan yang detil dan sederhana dari Joseph. A. Pipa, Jr. "Penciptaan dan Providensi" dalam Penuntun ke Dalam Theologi Institutes Calvin (ed. David A. Hall dan Peter Lillback; Surabaya: Momentum 2009).

40 Calvin, Institutes, 1.16.1.
} 
providensi menyatakan bahwa "he is also everlasting Governor and Preserver not only in that he drives the celestial frame as well as its several parts by a universal motion, but also in that he sustains, nourishes, and cares for, everything he has made, even to the least sparrow [cf. Matt. 10:29]."41 Dengan demikian, tidak ada sesuatu yang bersifat kebetulan. Apabila seseorang tiba-tiba jatuh ke tangan pencuri, dan segala macam kemalangan, atau jika seseorang yang tersesat di padang gurun tiba-tiba menemukan pertolongan, semua itu bukan kebetulan. Doktrin providensi mensyaratkan semua itu dikaitkan dengan Tuhan. ${ }^{42}$

Dalam pandangan Calvin, kemahakuasaan Allah harus diparadigma sebagai benar-benar penguasaan Allah atas alam semesta. Kemahakuasaan berarti Allah menaklukan segala realitas dan tidak ada sesuatupun yang dapat berlangsung atau terjadi di luar kontrol Allah. ${ }^{43}$ Calvin berpandangan bahwa pemerintahan Allah atas alam semesta dijalankan melalui dua sisi yakni bahwa Allah memelihara alam melalui hukum alam yang Ia ciptakan sendiri tetapi juga bahwa Allah memelihara alam melalui perhatian secara khusus kepada setiap bagian dari pekerjaan-Nya dalam dunia. ${ }^{44}$ Providensi berarti Allah bukan hanya secara umum tetapi Allah dengan aktif, secara khusus, spesifik dan detil menguasai segala ciptaan. Bukan saja demikian, Calvin menunjukan bahwa Kitab Suci dengan jelas mengajarkan peranan Allah yang aktif dalam menopang dan memerintah dunia (Yoh. 5:17; Kis.

\footnotetext{
41 Ibid., 1.16.1.

42 Ibid., 1.16.2.

43 Ibid., 1.16.3.

44 Ibid., 1.16.4.
} 
17:28; Ibr. 1:3).45

\section{Kedaulatan Allah dalam Eksistensi Pemerintahan}

Bagi Calvin, seperti yang telah dibahas sebelumnya, pemerintah menerima otoritas dan mandat dari Allah. ${ }^{46} \mathrm{Hal}$ ini membuktikan bahwa pemerintah bukanlah hasil seleksi alam yakni tirani baru yang dihasilkan oleh sistem anarki yang telah berlangsung. Dalam bahasa Meeter, pemerintah bukan merupakan kontrak sosial protektif menghadapi serangan atau merupakan desain manusia untuk menjawab kebutuhan kehidupan yang semakin kompleks. Dalam pandangan Meeter, kaum Calvinis kerap juga dapat memahami eksistensi negara berdasarkan dorongan sosial atau "Sozial-trek" atau "gregarious instinct" yang ditempatkan dalam diri manusia sebagai Imago Dei. Namun "cohesive social instinct" tersebut tidak cukup untuk menjelaskan asal mula negara. ${ }^{47}$ Eksistensi pemerintahan merupakan rancangan Allah untuk memelihara ciptaan-Nya. ${ }^{48}$ Eksistensi pemerintah adalah ekspresi kedaulatan Allah karena pemerintah didirikan dengan inisiatif Tuhan, pada waktu Tuhan, dengan alasan eksistensi yang juga berasal dari Tuhan. Bukan sampai di situ saja, pemerintah juga menerima otoritas dari Allah untuk menjalankan fungsi keadilan dan fungsi kesejahteraan ${ }^{49}$ sesuai dengan apa yang tertulis

\footnotetext{
45 Calvin, Institutes, 1.16.4-7.

46 Ibid., 4.20.4.

47 Meeter, The Basic Ideas of Calvinism, 78.

48 Calvin, Institutes, 4.20.4, 6.

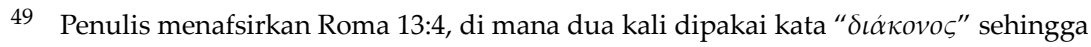
pemerintah mempunyai dua fungsi yakni fungsi keadilan dan fungsi kesejahteraan. Fungsi
} 
dalam Roma 13:4. Bagi Francis Schaeffer, otoritas yang diterima pemerintah adalah "delegated authority" bukan "autonomous authority." 50

Karena itu, Calvin menghendaki dalam diri pemerintah direpresentasikan sejumlah citra pemeliharaan Allah ${ }^{51}$ sehingga manifestasi publik dari kekristenan secara khusus dan kemanusiaan secara umum dapat terpelihara. $^{52}$ Tidak heran Calvin mengkritik Anabaptis habis-habisan karena upaya mereka menyingkirkan pemerintah. Pemerintah adalah desain Allah yang bukan untuk disingkirkan tetapi ditebus dan digembalakan agar berjalan sesuai dengan rancangan Allah. Konsep kedaulatan Allah membuat pemerintahan tidak bisa berjalan secara what is atau sesuai apa adanya tetapi ada what ought atau preskripsinya.

Kedaulatan Allah juga diperlihatkan dalam teologi politik Calvin dalam hal pemberantasan atas anarki. Calvin bukan hanya menyebut anarki sebagai sesuatu yang jahat, sebaliknya Calvin juga melegitimasi penguatan posisi pemerintah, sebagai desain Allah untuk memberantas "tikus-tikus dalam jerami." 53 Eksistensi pemerintah adalah sekaligus bagian dari wahyu umum dan anugerah umum. Berkhof berkata bahwa salah satu elemen

keadilan ditafsirkan dari tugas pemerintah sebagai Hamba Allah untuk menjatuhkan murka Allah bagi manusia berdosa. Sedangkan fungsi kesejahteraan diambil dari peran pemerintah sebagai Hamba Allah bagi kesejahteraan rakyat. Mengenai dua fungsi ini, bisa lihat Meeter, The Basic Ideas of Calvinism, 98-108. Meeter mengatakan, "a good government will seek to obtain through two general lines of activity: (1) the administration of justice and (2) the promotion of the general welfare of the stated and of its citizens".

50 Francis A. Schaeffer, A Christian Manifesto (Wheaton: Crossway, 1982), 91.

51 Calvin, Institutes, 4.20.6.

52 Ibid., 4.20.2-3.

53 Terjemahan dari kalimat "those who would have men live pell-mell, like rats in straw", dikutip oleh McNeill pada catatan kaki nomor 15 dalam Calvin, Institutes, 4.20.5. 
wahyu umum adalah "providential government of the world."54 Pemerintah adalah bagian dari wahyu umum dalam pengertian bahwa ketika Allah memakai pemerintah untuk menjatuhkan murka Allah atas orang yang berbuat jahat (Rm 13:4) maka Allah menyatakan diri-Nya (reveal - revelation) sebagai pemelihara ciptaan. Dengan kata lain, murka Allah yang direpresentasikan oleh pemerintah adalah ekspresi wahyu umum. Kuyper berkata, pemerintah adalah - "'common grace' to thwart all license and outrage and to shield the good against the evil."55 Calvin menyebutnya, "a wellconstituted republic is a singular benefit of God." 56 Hesselink mengatakan "civil government is a gift of God."57 Stevenson mengatakan "the gift of civil government thus demonstrates clearly the reality of God's providential care... God through his 'common grace' (generalis gratia) continues to shower his world with small sources of comfort, pleasure and enlightenment."58 Pemerintah adalah anugerah umum dalam pengertian bahwa Allah mengasihi seluruh umat manusia - dalam pengertian tertentu, misalnya tugas ekologis, pemerintah juga memberkati alam -, tidak hanya mereka yang diselamatkan sehingga Allah memelihara mereka dari kehancuran.

Dalam pandangan Calvin, pendorong terutama manusia mentaati pemerintah adalah karena pemerintah menerima mandat dari Allah. Sebaliknya, ketika pemerintah mencoba melawan Allah maka ia sedang

\footnotetext{
54 Berkhof, Systematic Theology, 36.

55 Abraham Kuyper, Lectures on Calvinism (Grand Rapids: William B. Eerdmans, 1931), 82.

56 Dari Sermon XXIX pada teks 1 Samuel 8:11-22, dikutip oleh Kelly, The Emergence of Liberty, 17.

57 I. John Hesselink, Calvin's First Catechism: a Commentary (Louisville: Westminster John Knox, 1997), 168.

58 Stevenson, "Calvin and Political Issues", 174.
} 
menghina kekuasaannya sendiri sehingga turbulensi gerakan sosial, yang sudah tentu dibangkitkan oleh Allah, akan menjadi gerakan pembangkangan sipil yang tak terbendung. ${ }^{59}$

\section{Kedaulatan Allah melawan Penguasa Tiran ${ }^{60}$}

Kedaulatan Allah terlihat dalam konsep bahwa Allah sanggup membangkitkan para pahlawan pembebas untuk melawan pemerintah lalim dan membebaskan kaum tertindas. ${ }^{61}$ Allah yang berprovidensi, yang menguasai alam semesta, bukan hanya menguasai para tiran tetapi juga menguasai para pahlawan pembebas. Salah satu contoh yang sangat menarik adalah ketika Raja Yoyakim membunuh nabi Uria dan mayatnya dibuang ke kuburan rakyat jelata (Yer. 26:23). Sebagai perbandingan, pada saat Yosia dipakai Allah mereformasi kerohanian dan ibadah bangsa Yehuda, semua barang-barang berhala dibakar dan abunya dibuang ke kuburan rakyat jelata. Jadi apa yang dilakukan oleh Yoyakim kepada raja Uria bersifat sangat menghina. Tetapi kemudian Tuhan membangkitkan bangsa Kasdim (Hab. 1:5; Yer. 22:26) dan Raja bangsa Kasdim, Nebukadnezar membunuh Yoyakim secara kejam, dikuburkan seperti keledai dan mayatnya dilemparkan keluar dari pintu-pintu gerbang Yerusalem (Yer. 22:19). Tuhan membalas kefasikan Yoyakim, lebih kejam

\footnotetext{
59 John Calvin, Calvin Commentaries: Acts 14-28 \& Romans 1-16 (Grand Rapids: Baker, 2009), 478-479.

60 Kritik Calvin terhadap pemerintahan tiranis, baik kritik dalam Institutes maupun dalam tafsiran-tafsiran telah dibahas oleh penulis dalam Un, "Bentuk Pemerintahan Menurut John Calvin", 35-38.
}

61 Calvin, Institutes, 4.20.30. 
dari apa yang ia lakukan kepada nabi Uria. Tuhan dipermuliakan melalui murka-Nya atas orang fasik.

Menghadapi penguasa tiran, Allah memperlihatkan kedaulatan-Nya, bukan hanya dengan membangkitkan pahlawan-pahlawan pembebas yang gagah perkara, bukan hanya berkuasa menggerakkan bangsa-bangsa asing untuk mewakili Allah menjatuhkan murka-Nya, tetapi juga berkuasa memakai orang-orang sederhana seperti bidan-bidan Ibrani ${ }^{62}$ untuk berani tidak mentaati apa yang diperintahkan oleh Firaun, raja dalam kekaisaran terbesar di dunia waktu itu. Allah yang berdaulat jauh lebih besar melampaui Firaun sekalipun. Allah yang berdaulat atas alam semesta dan Allah yang sanggup bekerja secara spesifik, berkuasa memakai bidan-bidan Ibrani yang sederhana, menggerakkan Puteri Firaun untuk mandi dan akhirnya bertemu dengan bayi Musa, serta menggerakkan Musa, mantan buronan kelas wahid Istana Firaun untuk kembali lagi ke "sarang penyamun", bukan untuk menyerahkan diri tetapi untuk menentang dan menantang Firaun agar melepaskan bangsa Israel keluar dari perbudakan Mesir.

Dalam tafsiran 1 Samuel 8, kedaulatan Allah nyata melalui pandangan bahwa Allah tidak memberikan otoritas kepada raja untuk memimpin secara kejam. ${ }^{63}$ Calvin justru mengingatkan para penguasa tiran bahwa mereka tidak boleh menjadikan rakyat hamba bagi kebaikan mereka karena mereka sendiri adalah hamba di hadapan Allah. Meskipun Calvin

\footnotetext{
62 John Calvin, Calvin's Commentaries: Harmony of Exodus, Leviticus, Numbers, Deuteronomy (Grand Rapids: Baker, 2009), II:33-35.
}

63 Teks dalam Hall, Calvin in the Public Square, 85. 
tidak menyetujui pemerintah lalim, namun ia tidak memparadigmakan pemerintah lalim sebagai penguasa tertinggi yang lepas dari kontrol Allah. Bagi Calvin, eksistensi pemerintah lalim diijinkan oleh Allah sebagai alat penghukuman Tuhan bagi manusia berdosa. ${ }^{64}$ Jadi, dapat dikatakan bahwa penguasa tiran sepenuhnya berada dalam kendali Allah. Allah yang mengijinkan eksistensinya, memperkenankan otoritasnya serta memberi batasanya. Allah mengijinkan penguasa tiran dalam rangka rancangan dan tujuan Allah serta pada saat-Nya, Allah membangkitkan pahlawanpahlawan pembebas untuk menjatuhkan penguasa tiran.

\section{Kedaulatan Allah dalam Hukum Pemerintahan ${ }^{65}$}

Supremasi hukum dan doktrin ekuitas menunjukkan bahwa Calvin mendasarkan pemikiran politiknya pada kedaulatan Allah. Konsep supremasi hukum di mana hukum adalah "silent magistrate"66 yang memimpin pemerintahan, merupakan proyek pemangkasan kemandirian dan sifat tak terkontrol dari pemerintah. Kita boleh menyebut bahwa supremasi hukum adalah bagian dari proyek penyangkalan diri sementara doktrin ekuitas adalah bagian dari memikul salib, yakni melakukan kehendak Bapa di surga. Doktrin ekuitas mensyaratkan hukum yang dirumuskan pemerintahan adalah berbasiskan hukum Taurat - yang adalah

\footnotetext{
64 Selain di dalam khotbah 1 Samuel 8 yang telah dibahas oleh penulis sebelumnya, Calvin juga menyatakan ide bahwa pemerintah lalim adalah alat penghukuman Tuhan dalam Institutes, 4.20.25.

65 Pembahasan Calvin tentang pentingnya hukum dalam kerangka pemerintahan aristokratisdemokratis telah disajikan oleh penulis dalam Un, "Bentuk Pemerintahan Menurut John Calvin", 40-42.

66 Calvin, Institutes, 4.20.14.
} 
hukum moral - yang tertulis di dalam hati nurani manusia sebagai wahyu umum. ${ }^{67}$ Calvin percaya bahwa hukum Tuhan yang tertulis dalam hati nurani dalam diri semua manusia ${ }^{68}$ sebagai wahyu umum, adalah dasar bagi semua hukum sipil pada bangsa-bangsa yang berbeda. Sebenarnya, dengan Allah menanamkan hukum Taurat dalam hati nurani manusia secara khusus, dan wahyu umum secara umum, Allah ingin menjalankan pemerintahan dan kedaulatan-Nya atas manusia.

\section{Kedaulatan Allah dalam Kepemimpinan Kolektif}

Bagi Calvin, inovasi segar Yitro bukan berasal dari manusia. Jelas hal ini merupakan desain Allah untuk memelihara kebebasan mereka dalam kebenaran. ${ }^{69}$ Usulan Yitro yang demikian cemerlang, yang dianggap oleh Calvin sebagai "early federal scheme"70 berasal dari pimpinan dan kehendak Allah. Calvin sangat sadar akan pemeliharaan Allah di dalam bentuk pemerintahan yang berbeda-beda. Pemeliharaan Allah tersebut dinyatakan dalam konteks setiap negara yang berbeda sehingga memang memerlukan bentuk pemerintahan yang berbeda pula.

Di kemudian hari, atas pengaruh dari pemikiran politik Calvin, para pendiri Amerika Serikat menambahkan doktrin providensi Allah dalam the Declaration of Independence di dalam kalimat "a firm reliance on the protection of divine Providence." Para pendiri negara adidaya tersebut bukan saja percaya

\footnotetext{
67 Calvin, Institutes, 4.20.15-16.

68 Calvin, Calvin's Commentaries: Acts 14-28 \& Romans 1-16, 97-98.

69 Hall, Calvin in the Public Square, 83-84.

70 Hall, Calvin in the Public Square, 84.
} 
Allah ada tetapi bahwa Allah berdaulat atas seluruh ciptaan - dan tentunya sebagaimana dikatakan Benjamin Franklin, Allah juga "governs in the affairs of men." 71

\section{Doktrin Dosa}

Presaposisi dosa - kejatuhan serta ketidakmampuan manusia - di balik teologi Calvin, secara khusus pemikiran politiknya, sudah dipelajari selama masa pendidikan di Paris, yakni pengaruh dari antropologi Agustinus.72 Dalam konteks teologi politik, presaposisi dosa secara khusus, dan antropologi secara umum memiliki tempat yang krusial, sebagaimana ditegaskan John Eidsmoe, "one's view of human nature does than profoundly affect one's view of government."73 Eidsmoe mengembangkan prinsip ini kemudian menjadi "any theory of government must be based on a realistic view of human nature."74 Karena itu, signifikan untuk membahas konsep dosa yang menjadi presaposisi di balik teologi politik Calvin.

\section{Defenisi Dosa}

Dalam analisanya, Calvin menyetujui Agustinus dalam pernyataan bahwa kesombongan adalah awal semua kejahatan, sebab ambisi membawa manusia lebih tinggi dari apa yang ada, sehingga manusia tidak lagi berada dalam statusnya semula. Namun demikian, dalam pandangan Calvin,

71 Dikutip John Eidsmoe, Christianity and the Constitution (Grand Rapids: Baker, 1987), 363.

72 Alister McGrath, A Life of John Calvin (Cambridge, MA: Basil Blackwell 1990), 45.

73 Eidsmoe, Christianity and the Constitution, 20.

74 Ibid., 369. 
ketidaktaatanlah yang merupakan dosa mula-mula. Dalam pengaruh penipuan setan, Hawa menyimpang dan tidak setia kepada firman Tuhan. ${ }^{75}$ Dasar argumentasi yang digunakan Calvin adalah pernyataan Paulus bahwa oleh ketaatan satu orang semua orang dibenarkan, demikian pula oleh ketidaktaatan satu orang, dosa dan maut menjalar dan menguasai manusia $(\operatorname{Rm} 5: 19)$.

Calvin menjelaskan,

"the first man revolted from God's authority, not only because he was seized by Satan's blandishments, but also because, contemptous of truth, he turned aside to falsehood. And surely, once we hold God's Word in contempt, we shake off all reverence to him. For unless we listen attentively to him, his majesty will not dwell among us, nor his worship remain perfect. Unfaithfulness, then was the root of the Fall" ${ }^{76}$

Dari ketidaksetiaan memimpin kepada kesombongan. Ambisi dan kesombongan yang dicampur dengan perasaan tidak berterima kasih telah menghasilkan kesesatan atau apostasy. ${ }^{77}$ Adam seolah tidak merasa puas dengan desain Tuhan untuk menjadi gambar dan rupa-Nya. Adam menginginkan kesetaraan dengan Allah. Calvin menyebut hal ini sebagai " $a$ monstrous wickedness."78 Calvin menyimpulkan,

"lastly faithlessness opened the door to ambition, and ambition was indeed the mother of obstinate disobedience; as a result, men, having cast off the fear of God, threw themselves whereever lust carried them... For Adam would never have dared oppose

75 Calvin, Institutes, 2.1.4.

76 Ibid., 2.1.4.

77 Ibid., 2.1.4. Bandingkan Ford Lewis Battles, Analysis of the Institutes of the Christian Religion of John Calvin (Phillipsburg: P\&R, 1980), 86.

78 Ibid., 2.1.4. 
God's authority unless he had disbelieved in God's word". ${ }^{79}$

Dosa pertama adalah dosa asal. Karena itu, kutukan yang menyebar ke seluruh dunia memancar keluar dari dosa Adam. Calvin berpandangan bahwa dosa asal merupakan pewarisan keadaan terkorup, suatu deviasi terhadap hal-hal yang baik dan murni. ${ }^{80}$ Argumentasi Alkitabiahnya adalah perkataan Daud yang terkenal dalam Mazmur 51:5, Daud mengaku bahwa dirinya telah dikandung dan diperanakkan dalam dosa. Calvin menyimpulkan,

"therefore all of us, who have descended from impure seed, are born infected with the contagion of sin. In fact, before we saw the light of this life we were soiled and spotted in God's sight 'for who can bring a clean thing from an unclean? There is not one' as The Book of Job says [Job 14:4]." ${ }^{11}$

Pada bagian berikutnya, Calvin mendefenisikan,

"original sin, therefore, seems to be a hereditary depravity and corruption of our nature, diffused into all parts of the soul, which first makes us liable to God's wrath, then also brings forth in us those works which Scripture calls 'works of the flesh' (Gal. 5:19). And that is properly what Paul often calls $\sin ^{\prime \prime} .82$

Dosa asal bukan diturunkan melalui imitasi melainkan melalui analogi infeksi. Bagi Calvin, Adam bukan hanya "the progenitor" tetapi juga "the root of human nature" sehingga dalam dan dari dosa Adam, umat manusia kemudian terus menerus diperburuk. ${ }^{83}$ Argumentasi Alkitabiahnya

\footnotetext{
79 Ibid., 2.1.4.

80 Calvin, Institutes, 2.1.5.

81 Ibid., 2.1.5.

82 Ibid., 2.1.8.

83 Ibid., 2.1.6.
} 
adalah Roma 5:12, 17 di mana Paulus membandingkan Adam dan Kristus. Dosa masuk melalui Adam dan kebenaran diturunkan melalui Kristus. Konsep Pelagius, dosa Adam diturunkan melalui imitasi dikritik habishabisan oleh Calvin. Dampaknya, jika dosa diturunkan secara imitasi maka kebenaran pun diberikan secara imitasi. Hal ini adalah sebuah ketidakmungkinan. Transmisi secara imitasi tidak mempresaposisikan hadirnya dimensi supranatural baik dalam dosa maupun kebenaran. Calvin menyimpulkan bahwa dalam dosanya, Adam telah menghancurkan keturunannya dengan menyebarkan suatu infeksi. ${ }^{84}$

Bagi Calvin, dosa telah mencemari seluruh aspek hidup manusia. Calvin berkata,

"here I only want to suggest briefly that the whole man is overwhelmed - as by a deluge - from head to foot, so that no part is immune from sin and all that proceeds from him is to be imputed to sin. As Paul says, all turning of the thoughts to the flesh are enmities against God (Rom 8:7), and are therefore death (Rom 8:6)" ${ }^{85}$

Setelah manusia melawan Tuhan dan jatuh dalam dosa maka terjadi dampak-dampak sosial mulai dari Adam menyalahkan Hawa dan langsung dilanjutkan dengan aksi Kain membunuh Habel dalam Kejadian 4, satu pasal setelah kejatuhan dalam dosa. Cornelius Platinga, Jr menempatkan konsep dosa dan dimensi sosialnya dalam paradigma penciptaan shalom. Ia menemukan bahwa para nabi

"menyebut jalinan yang kuat antara Allah, manusia dan seluruh ciptaan dalam keadilan, kepenuhan dan sukacita sebagai shalom. Kita menyebutnya damai, tetapi shalom memiliki makna yang jauh lebih luas dari sekadar

84 Calvin, Institutes, 2.1.6.

85 Ibid., 2.1.9. 
kedamaian pikiran atau gencatan senjata. Dalam Alkitab, shalom berarti kelancaran, keutuhan dan sukacita universal - suatu kondisi berlimpah yang di dalamnya kebutuhan alami dipuaskan dan karunia alami dipakai dan berbuah, suatu kondisi yang membangkitkan ketakjuban yang penuh sukacita tatkala Sang Pencipta dan Sang Juruselamat membuka pintu dan menyambut ciptaan yang Ia perkenan. Dengan kata lain, shalom adalah bagaimana segala sesuatu seharusnya menjadi... Dalam kondisi shalom, tiap hal akan memiliki integritas atau kepenuhan yang terstruktur dan tiap hal juga memiliki keterkaitan yang saling mendukung dengan banyak hal lain" ${ }^{86}$

Sebagaimana yang telah dikemukakan di atas, dosa bersifat religius, artinya memiliki dimensi vertikal yakni melakukan apa yang jahat di mata Tuhan. Namun demikian, dalam paradigma shalom, dosa memiliki dimensi lain. Platinga berkata,

"Allah membenci dosa bukan hanya karena dosa melanggar hukum-Nya, tetapi terlebih karena dosa melanggar shalom, merusak kedamaian, menghalangi sesuatu untuk menjadi yang seharusnya. (Bahkan inilah alasan Allah menetapkan berbagai hukum untuk melawan dosa). Allah berpihak kepada shalom dan oleh karena itu, Dia melawan dosa." 87

Platinga menambahkan, "dosa mendukakan hati Allah bukan hanya karena dosa mengabaikan dan menyerang Allah secara langsung, seperti saat kita berbuat fasik atau menista Allah, melainkan juga karena dosa mengabaikan dan menyerang apa yang Allah ciptakan."88 Bahwa dosa merusakkan rancangan indah Allah dalam ciptaan, salah satunya tampak dari meningkatnya dosa-dosa sosial sejak kejatuhan. Mulai dari pengkambinghitaman di Kejadian 3, pembunuhan di pasal 4. Kemudian, -

\footnotetext{
86 Cornelius Platinga, Jr, Tidak Seperti Maksud Semula (Surabaya: Momentum, 2004), 10. Penekanan oleh Platinga sendiri.

87 Platinga, Tidak Seperti Maksud Semula, 14. Penekanan oleh Platinga sendiri.

88 Ibid., 17.
} 
masih dalam pasal yang sama dengan tangan Kain penuh darah - Lamekh menetapkan aturan balas dendam dan pembunuhan yang semakin luar biasa di tengah-tengah komunitas primitif peternak, musisi dan pengrajin logam. "Peradaban bertumbuh", kata Platinga, "tetapi kejahatan juga meningkat." 89 Hingga datangnya air bah, pemusnahan ciptaan, yang dianggap oleh David J. A Clines sebagai "tahap akhir dalam proses disintegrasi kosmis yang diawali di Taman Eden." 90

Jadi, bagi Calvin, dari dosa pertama, dosa Adam, ketidakpercayaan sebagai akar yang memanifestasikan dirinya kepada keangkuhan dan ketidaktaatan akhirnya menyebar kepada seluruh umat manusia karena Adam adalah akar dari umat manusia. Dosa kini telah mencemari seluruh umat manusia dan dalam diri setiap manusia, tidak ada lagi bagian yang masih bersih dari dosa. Semuanya sudah tercemar. Di sini Calvin mengajarkan doktrin universalitas dan totalitas dosa yang pada gilirannya memberi dampak sosial. Dosa tidak pernah tidak memiliki dimensi sosial. Dosa dimulai dari dimensi vertikal - melakukan apa yang jahat di mata Tuhan - lalu kemudian mewujudkan dirinya dalam dimensi horisontal.

\section{Doktrin Dosa dan Eksistensi Pemerintahan}

Universalitas dosa dan totalitas dosa menghasilkan dampak-dampak sosial. Dosa-dosa secara horizontal terjadi, seperti konflik sosial, kerusuhan, sengketa yuridis, gangguan ketertiban publik, dan ragam kriminalitas lainnya. Karena itu Allah berinisiatif mendirikan pemerintah sebagai order of

\footnotetext{
89 Ibid., 31.

90 Dikutip Platinga, Ibid., 31.
} 
preservation. Tidak heran, Allah memberikan otoritas kepada pemerintah sebagai hamba-Nya untuk menjatuhkan murka Allah atas orang yang berbuat jahat (Rm 13:4). Dalam pembahasan mengenai tugas pemerintah untuk memberantas anarki, Calvin menyatakan dengan jelas, tugas dan fungsi yang berkaitan dengan pemberantasan dosa-dosa sosial. ${ }^{91}$

Stevenson mengatakan bahwa pemerintah dibangkitkan sebagai "God's providential ordination", baik sebagai konsekuensi maupun sebagai "partial remedy for human sin."92 Pemerintah hadir sebagai konsekuensi logis eksistensi dosa artinya dosa yang menyebabkan sengketa dan konflik sosial yang mensyaratkan penyelesaian - demi bertahannya manusia dan masyarakat. ${ }^{93}$ Sedangkan pemerintah adalah sebagian kecil dari penyelesaian dosa artinya pemerintah adalah wakil Allah untuk menjalankan fungsi keadilan - termasuk menjatuhkan murka Allah atas orang yang melawan Tuhan. Tanpa pemerintah, "even minimally constructive relationships among human beings would be difficult to imagine."94

\footnotetext{
91 Calvin, Institutes, 4.20.2-3.

92 Stevenson, "Calvin and Political Issues", 173.

93 Menarik sekali, Meeter mengatakan bahwa jika dunia tidak jatuh dalam dosa pun pemerintah akan tetap ada dalam pengertian "a state" yaitu sebuah masyarakat manusia di bawah pemerintahan di mana beberapa orang diakui dan diangkat sebagai pemimpin. Bahkan, negara ini adalah negara sempurna yakni Kerajaan Allah. Bukti dari penjelasan ini terdapat pada fakta Alkitab bahwa di dalam "masyarakat" malaikat yang tanpa dosa pun terdapat penghulu (archangel) Michael dan beberapa malaikat dikatakan diberi tahta, kekuasan dan kuasa atas malaikat yang lain. Juga dalam langit dan bumi yang baru, ada terdapat kuasakuasa. Misalnya, 12 rasul akan diberi kuasa menghakimi 12 suku Israel. Juga mereka yang mendapatkan 10 dirham akan diberi kekuasaan atas 10 kota (Luk. 19:12-17). Tugas pemerintahan dalam dunia tanpa dosa, bukan untuk penegakkan hukum melainkan tugas kultural. Bentuk pemerintahannya adalah Monarki di mana Kristus menjadi Raja dan Adam adalah kepala pemerintahan. Lihat, Meeter, The Basic Ideas of Calvinism, 78, 83.

94 Stevenson, "Calvin and Political Issues", 173.
} 
Bahwa konsep dosa ada di dalam pemikiran Calvin pada waktu membicarakan tentang urgensi eksistensi pemerintahan, terlihat jelas dalam tugas dan fungsi-fungsinya. Fungsi dan karakter pemeliharaan yang dilekatkan Allah pada pemerintahan, berkenaan dengan eksistensi dosadosa sosial telah disebutkan Calvin. Beberapa di antaranya adalah memelihara orang baik terhadap serangan orang jahat, kriminaliasi, penindasan dan lain sebagainya. Apa yang diharapkan dari pemerintah adalah suatu perlindungan terhadap ketertiban dan keamanan publik. ${ }^{95}$

Calvin berkata, pemerintah juga berfungsi untuk memelihara ekspresi ibadah kepada Allah yang dilakukan secara eksternal/ publik, bukan hanya di dalam hati dan di dalam ruang tertutup karena sejatinya dosa mengakibatkan manusia bisa mengganggu dan menyerang ibadah. ${ }^{96} \mathrm{Lalu}$, pemerintah juga hadir untuk menolong rakyat dalam penyesuaian sosial yakni rekonsiliasi satu dengan yang lain dan mendorong terjadinya kebaikan di tengah masyarakat. Hal ini dilakukan karena dosa memungkinkan terjadinya keegoisan dalam masyarakat, sehingga muncul dosa-dosa sosial seperti perpecahan, permusuhan, dendam, iri hati, dengki, provokasi, kerusuhan dan seterusnya. Pemerintah bertugas "to promote general peace... prevents the public peace from being distrubed" karena dosa mengakibatkan kriminalitas meningkat, pencurian, perampokkan, pemerkosaan, terorisme, dan sebagainya. Tanpa hadirnya pemerintahan, manusia yang sudah jatuh dalam dosa akan sendirinya menghancurkan kemanusiaan. Pemerintah hadir agar "humanity be maintained among men".

\footnotetext{
95 Calvin, Institutes, 4.20.9.

96 Tugas-tugas pemerintah pada paragraf ini diambil dari Calvin, Institutes, 4.20.2-3.
} 
Ringkasnya, sebagaimana ditegaskan Schaeffer, "in this fallen world, God has given us certain offices to protect us from the chaos which is the natural result of that fallenness." 97

Tanpa kehadiran pemerintahan, dosa-dosa sosial horisontal terjadi, dan yang lebih parah lagi adalah masyarakat menyelesaikan kejahatan dengan kejahatan, dalam semangat dendam kesumat sehingga spiral kehancuran akan tiba. Kalau kita memperhatikan konteks terdekat dari Roma 13:1-7, maka Roma 12:17-21 yang menegaskan agar orang percaya tidak membalas kejahatan dengan kejahatan dan tidak mengambil langkah untuk menuntut pembalasan sendiri. Sebab, pembalasan adalah hak Tuhan. Ayat 19 berbunyi, "Saudara-saudaraku yang kekasih, janganlah kamu sendiri menuntut pembalasan tetapi berilah tempat kepada murka Allah sebab ada tertulis: pembalasan itu adalah hak-Ku. Akulah yang akan menuntut pembalasan, firman Tuhan". Karena itu, eksistensi pemerintahan yang dibahas dalam Roma 13 dapat dipahami merupakan ekstensi dari bagian yang melarang pembalasan. Manusia dilarang untuk membalas dendam, pembalasan adalah hak Tuhan dan Tuhan menetapkan pemerintah sebagai wakil Allah untuk membalaskan murka Allah bagi orang jahat (Rm 13:4b - "Pemerintah adalah hamba Allah untuk membalaskan murka Allah atas mereka yang berbuat jahat"). Dalam Roma 12:19, istilah "pembalasan" menggunakan istilah Yunani " $\varepsilon \kappa \delta \imath \kappa \eta \sigma \iota \varsigma$ " sedangkan Roma 13:4, istilah "membalaskan" menggunakan istilah Yunani " $\varepsilon \kappa \delta \imath \kappa o \varsigma^{\prime}$. Di sini, akar kedua istilah itu sama.

97 Schaeffer, A Christian Manifesto, 90. 
Eidsmoe menegaskan bahwa para pendiri Amerika Serikat - di bawah pengaruh dari teologi politik Calvin - berdasarkan konsep dosa sebagai latar belakang, bukan saja mendesain eksistensi pemerintahan tetapi juga mendorong penguatan pemerintahan sehingga dapat menangani kejahatankejahatan masyarakat sehingga tidak sampai tergelincir menjadi anarki dan kekacauan. Sebaliknya, karena pejabat pemerintah juga adalah orang berdosa sehingga tidak bisa dibiarkan memegang kuasa mutlak. Kalau tidak, penguasa akan menjadi tirani. Karena itu, para perumus konstitusi Amerika Serikat berkumpul dalam Great Convention tahun 1787 guna mengartikulasikan sistem checks and balances berkenaan dengan realitas dosa dan kejahatan. Eidsmoe menyimpulkan, "their solutions to this problem showed a Calvinistic background." 98

\section{Doktrin Dosa dan Perlawanan Terhadap Anarki ${ }^{99}$}

Istilah "anarki" berasal dari bahasa Yunani $\alpha \nu$ dan $\alpha \rho \chi o \varsigma$ yang berarti “tanpa pemerintah/pemimpin”. Seyogyanya, seorang anarkis adalah seorang yang menjadikan dirinya sebagai pemerintah atau pemimpin atau hukum itu sendiri. Adagiumnya adalah "I am the law". Pasca kejatuhan manusia dalam dosa, anarki terus berkembang melalui Kain dan mencapai puncaknya pada Lamekh yang adalah keturunan ketujuh ${ }^{100}$ dari Adam

\footnotetext{
98 Eidsmoe, Christianity and the Constitution, 21.

99 Kritik Calvin terhadap model politik anarkis, baik kritik dalam buku Institutes maupun kritik dalam tafsiran Kitab Kejadian telah dibahas oleh penulis dalam Un, “Bentuk Pemerintahan Menurut John Calvin", 31-35. Dalam bagian tersebut, penulis memperlihatkan bahwa Calvin lebih berpihak kepada tirani ketimbang kepada anarki.

100 Kita bisa membandingkan Lamekh yang adalah keturunan ketujuh dengan Henokh yang juga adalah keturunan ketujuh dari Adam. Henokh berbeda dengan Adam, berbeda dengan
} 
melalui jalur Kain (Kej. 4). Kain membunuh Habel, dan tidak mau mentaati peringatan Tuhan. Tuhan memproteksi Kain dengan mengancam barangsiapa membunuh Kain, kepadanya akan dibalaskan tujuh kali lipat. Meskipun Kain melakukan anarki dan membunuh Habel, namun peraturan proteksinya ditentukan oleh Tuhan. Sedangkan Lamekh, ia sendiri menentukan pengaturan pembalasannya. Bila orang memukulnya, Lamekh akan membalaskan dengan pembunuhan. Bila kain dibalaskan tujuh kali lipat, Lamekh menuntut pembalasan tujuh puluh kali tujuh (Kej. 4:23-24). Jika pada Kain, Tuhan yang menentukan pengaturan pembalasan, maka pada Lamekh, ia menentukan sendiri. Jika pada Kain, Tuhan menetapkan agar pembunuhan Kain akan dibalaskan dengan pembunuhan, sedangkan pada Lamekh, ia menetapkan bahwa penganiayaannya akan dibalaskan dengan pembunuhan. Jika pada Kain akan dibalaskan tujuh kali lipat, pada Lamekh, pembalasannya sebelas kali lebih keras, yakni akan dibalaskan kepada yang membunuhnya tujuh puluh tujuh kali.

Konsepsi "I am the law", terlihat jelas bahwa dalam kitab HakimHakim, bahwa "setiap orang melakukan apa yang ia pandang benar" (21:25). Hal inilah yang dimaksudkan oleh Calvin sebagai tikus dalam jerami, setiap ekor bertindak menurut apa yang menyenangkannya. Pembunuh, jika dibiarkan akan tak terkendali dan liar. Karena itu, Tuhan mempercayakan kepada pemerintah sebagai hamba-Nya, sebilah pedang.

semua leluhurnya dan juga terutama berbeda dengan Lamekh karena Henokh bergaul dengan Allah (Kej. 5:24). Lamekh adalah puncak kejahatan sedangkan Henokh adalah puncak kesetiaan orang percaya kepada Allah. 


\section{Doktrin Dosa dan Perlawanan Terhadap Tirani ${ }^{101}$}

Dosalah yang mengakibatkan penguasa menjadi despotis dan kejam. Ketika para tiran telah dikuasai oleh ambisi dan hawa nafsu maka akan sulit mengontrol diri mereka dan menyesuaikan kehendak mereka dengan prinsip kebenaran dan keadilan. Apalagi, jika tidak ada kontrol sosial dari luar. Raja-raja yang telah dikuasai oleh hawa nafsu, misalnya, akan dengan kejam dan tak berperasaan merampas gadis-gadis belia dari rakyat atau budak atau tawanan untuk dijadikan selir atau gundik, padahal mereka sudah mempunyai istri yang demikian banyak. Tidak heran, Salomo bisa mempunyai istri dan selir sebanyak seribu orang (1 Raj. 11:3)!

Samuel Rutherford mengatakan bahwa "a power ethical, politic, or moral, to oppress, is not from God, and is not a power, but a licentious deviation of a power, and is no more from God, but from sinful nature and the old serpent, than a license to sin."102 Rutherford mengatakan bahwa tirani adalah bersifat satanik. Karena itu, pembiaran kepada tirani sama dengan perlawanan kepada Allah. Melawan tirani justru adalah penghormatan kepada Allah. Hal ini mengakibatkan, bagi Rutherford, warga negara mempunyai kewajiban moral untuk melawan ketidakadilan dan pemerintah tirani. ${ }^{103}$ Singkatnya, dosa mengakibatkan pemerintah tirani memimpin dengan kejam dan dengan demikian harus dilawan oleh warga negara.

\footnotetext{
101 Calvin menyatakan bahwa hak perlawanan terhadap pemerintahan tiranis bukan diserahkan kepada rakyat banyak tetapi kepada inferior magistrates. Lihat pembahasan penulis dalam Un, "Bentuk Pemerintahan Menurut John Calvin", 40.

102 Dikutip oleh Schaeffer, A Christian Manifesto, 100.

103 Dikutip oleh Schaeffer, Ibid., 101.
} 


\section{Doktrin Dosa dan Kepemimpinan Kolektif}

Bahwa konsep dosa menjadi presaposisi bagi kebutuhan hadirnya kepemimpinan koletif, dinyatakan sendiri oleh Calvin,

"men's fault or failing causes it is to be safer and more bearable for a number to exercise government so that they may help one another, teach and admonish one another; and, if one asserts himself unfairly, there may be a number of cencors and masters to restrain his wilfulness." 104

Dalam pernyataan ini, kita melihat bahwa Calvin membicarakan penyebab dan penyelesaian sekaligus dalam satu ide. Penyebabnya adalah dosa yakni, jika tanpa kontrol maka kekuasaan yang berada di tangan orang berdosa akan cenderung korup dan despotis. Ini sebuah realita, bukan sekedar ide. Penyelesaiannya adalah kepemimpinan kolektif dan kontrol sosial yang menyertainya. Dengan sistem aritokrasi yang dipagari oleh demokrasi maka masyarakat diharapkan berada dalam kondisi terbaik. ${ }^{105}$ Presaposisi dosa menjadikan impian utopis Cicero bahwa bentuk pemerintahan monarki, aristokrasi dan demokrasi akan bisa berjalan baik apabila terdapat keadilan dan kebijaksanaan di dalamnya, sebagai sesuatu yang sungguh-sungguh utopia, sesuatu yang tidak mungkin terjadi. ${ }^{106}$

\section{Doktrin Dosa dan Hukum}

Hukum Taurat dalam pandangan Calvin, memiliki posisi sangat strategis dan signifikan, sebagai jiwa dari pemerintahan yang tanpanya

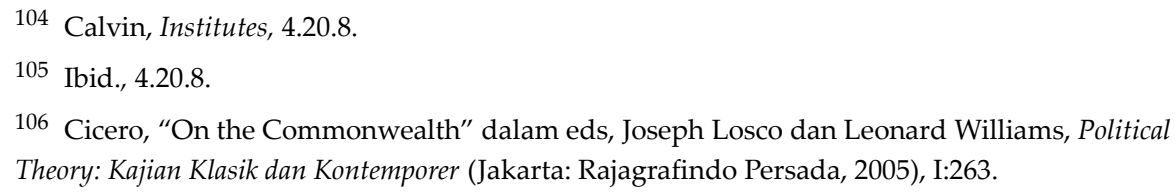


pemerintahan tidak bisa berdiri. ${ }^{107}$ Asumsi dosa berada di belakangnya. Karena tanpa hukum maka rakyat akan menjadi liar dan tak tekendali.

Bagi Calvin, hukum Taurat diparadigma sebagai cermin untuk membongkar dosa manusia. Hukum Taurat bisa menjadi cermin bagi manusia berdosa karena Hukum Taurat merupakan ekspresi kebenarankeadilan (righteousness) Tuhan. ${ }^{108}$ Hal ini berarti, salah satu akibat dosa adalah manusia tidak mau mengakui dosanya sehingga perlu cermin untuk menyatakan kebobrokan dan kebejatannya. Selain itu, manusia dalam dosa bukan saja tidak mengakui dosanya, malah melegitimasi dosa dengan argumentasi filosofis dan teologis yang sangat logis. Karena itu perlu cermin untuk membongkar dosa manusia.

Hukum Taurat harus ada sebagai penahan lajunya dosa manusia. ${ }^{109}$ Meskipun orang fasik dan orang durhaka tidak memiliki hati yang rela untuk mentaati Tuhan tetapi karena takut kepada penghukuman, secara eksternal mereka menahan diri untuk berbuat dosa. Hukum Taurat adalah teror bagi orang fasik sehingga mereka tidak berani bertindak secara tak terkendali. Meskipun kondisi ini bukanlah sesuatu yang ideal namun dapat dianggap sebagai anugerah umum karena memprevensi manusia lain dari kehancuran akibat dosa yang tidak dikendalikan oleh hukum. Karena manusia sudah jatuh dalam dosa dan kecenderungan hatinya adalah jahat semata-mata (Kej. 6:5) maka Allah terpaksa memakai cara keras untuk menaklukan orang fasik sehingga tidak bertindak yang pada akhirnya

\footnotetext{
107 Calvin, Institutes, 4.20.14.

108 Ibid., 2.7.6.

109 Calvin, Institutes, 2.7.10.
} 
menjadikan ciptaan secara umum, maupun manusia secara khusus masuk ke dalam kehancuran.

Jadi, kehadiran hukum Taurat, secara khusus melalui hukum moral yang tertulis dalam hati manusia berfungsi sebagai pernyataan kebenarankeadilan Allah dan penahan lajunya dosa manusia sehingga manusia dapat hidup dalam suasana yang damai dan kondusif. Pemerintahan aristokrasidemokrasi tidak berjalan tanpa hukum sebab hukum adalah silent magistrate dan pemerintah adalah living law. ${ }^{110}$

Berdasarkan pembahasan tersebut di atas maka kita dapat memahami bahwa di balik konsep supremasi hukum dalam bentuk pemerintahan republik, Calvin memiliki presaposisi dosa. Dosa adalah situasi yang harus diselesaikan dengan hukum yang adil dan suprematif. Justru Calvin menghindari pemerintahan tirani - pola Machiavellian - dalam menyelesaikan dosa dengan mempresaposisikan supremasi hukum.

Konsep supremasi hukum begitu penting dalam pemerintahan republik. Tidak heran ide ini kemudian diteruskan oleh seorang Calvinis asal Skotlandia yakni Samuel Rutherford (1600-1661) dalam bukunya Lex Rex (The Law and the Prince) yang ditulis pada tahun 1644. Konsep Lex Rex sangat sederhana yakni "the law is king" sehingga jika raja dan pemerintah tidak mentaati hukum maka pemerintah boleh tidak ditaati. Dasar dari pembuatan hukum ini adalah hukum Allah. Parlemen Skotlandia kemudian tidak menerima pandangan Rutherford sehingga ia divonis hukuman mati namun kemudian vonis tersebut batal dilaksanakan. Satu-satunya alasan

110 Ibid., 4.20.14. 
adalah karena Rutherford telah meninggal terlebih dahulu!111

\section{Kesimpulan}

Berdasarkan pembahasan di atas, dapat disimpulkan bahwa sesungguhnya pemikiran politik Calvin di dasarkan atas doktrin-doktrin teologis. Doktrin Alkitab memberikan landasan epistemologis bagi pemikiran politik Calvin. Meskipun Calvin berinteraksi dengan pemikiran politik dari filsafat Yunani, terutama Plato dan secara khusus melalui pintu Agustinus, dan juga mempelajari pemikiran filsuf Marcus Aurelius Cicero namun pendasaran Alkitab terutama Perjanjian Lama demikian kuat dalam pemikiran politiknya.

Doktrin kedaulatan Allah memberikan legitimasi bagi hadirnya pemerintahan. Pemerintahan atau negara bukanlah hasil kontrak sosial manusia dalam menghadapi seleksi alam atau merupakan ekspresi dari sifat sosial manusia sebagai gambar Allah melainkan penetapan Allah. Allah menetapkan pemerintah sebagai bagian pemeliharaan-Nya atas manusia dan juga atas alam semesta dari kehancuran akibat dosa-dosa sosial dan ekologis. Doktrin kedaulatan Allah juga berperan dalam memberikan pembatasan kepada ekses-ekses dari otoritas manusia terutama pemerintahan tiranis yang menindas manusia lain.

Sementara itu, doktrin dosa memberikan landasan faktual bahwa pemerintah, hukum, kepemimpinan kolektif menjadi suatu keniscayaan. Pemikiran politik Calvin seolah dijangkarkan pada suatu kesadaran

111 Dikutip dan dibahas dalam Schaeffer, A Christian Manifesto, 99. 
realisme bahwa dosa telah demikian mengancam kehidupan manusia sehingga Tuhan menghadirkan pemerintahan yang adil dan demokratis sebagai suatu bagian tertentu penyelesaian atas dosa. Penyelesaian sementara dan terbatas atas dosa, suatu penyelesaian natural dan kelihatan. 